\title{
ORAL MICROBIOTA OF BRAZILIAN CAPTIVE SNAKES
}

\author{
Fonseca MG (1), Moreira WMQ (2), Cunha KC (3), Ribeiro ACMG (1), Almeida MTG
}

(1) Parasitology and Zoology Laboratory, Piauí Federal University, Picos, Piauí State, Brazil; (2) Microorganism and Plant Biochemistry Laboratory, School of Agrarian Sciences and Veterinary Medicine, São Paulo State University, UNESP, Jaboticabal, São Paulo State, Brazil; (3) Microbiology Laboratory, São José do Rio Preto Medical School, FAMERP, São José do Rio Preto, São Paulo State, Brazil.

ABSTRACT: The present work aimed to determine the oral microbiotic composition of snakes from São José do Rio Preto city, São Paulo State, Brazil. Ten snake species, comprising the families Boidae, Colubridae, Elapidae and Viperidae, were submitted to microbiological examination of their oral cavity, which indicated positivity for all buccal samples. Gram-negative bacilli, gram-negative cocci bacilli, grampositive bacilli and gram-positive cocci were isolated from the snakes. Among isolated bacterium species, the occurrence of coagulase-negative staphylococci in the buccal cavity of Crotalus durissus (Viperiade), Eunectes murinus (Boidae), Mastigodryas bifossatus (Colubridae) and Bacillus subtilis, common to oral cavity of Bothrops alternatus (Viperidae) and Phalotris mertensi (Colubridae), was detected. It was observed higher diversity of isolated bacteria from the oral cavity of Micrurus frontalis (Elapidae) and Philodryas nattereri (Colubridae), as well as the prevalence of gram-positive baccillus and gram-positive cocci. The composition of the oral microbiota of the studied snakes, with or without inoculating fangs, is diverse and also related to the formation of abscesses at the bite site in the victims of the ophidian accidents, and to pathogenic processes in the snakes that host these microorganisms.

KEY WORDS: venomous snakes, non-venomous snakes, oral cavity, bacterial isolation, captive snakes.

CONFLICTS OF INTEREST: There is no conflict.

\section{CORRESPONDENCE TO:}

MARILUCE G. FONSECA, Universidade Federal do Piauí, Campus Senador Helvídio Nunes de Barros, Rua Cícero Eduardo s/n, Junco, CEP: 64600 000, Picos, Piauí, Brasil. Email: marilucefonseca@ufpi.edu.br. 


\section{INTRODUCTION}

Studies on oral microbiota of snakes are rare in Brazil and the existing reports are mainly on the Bothrops genus, which is involved in most of the reported accidents (15). Envenomation caused by this snake genus is characterized by inflammation and tissue destruction that leads to infection and abscess formation (6-9).

Among snakes that contribute to accidents in Brazil, four genera - Micrurus (with proteroglyph dentition); Bothrops, Crotalus and Lachesis $(10,6)$ (with solenoglyph dentition) - are considered common. However, some snakes with opistoglyph and aglyph dentition, considered non-venomous, can also cause injuries at the bite site and, consequently, complications that determine the seriousness of the accidents (11).

Currently, several hypotheses try to explain infectious origins in lesions caused by ophidian accidents. In one of these theories, bacteria - from the venom, mouth and fangs of snakes - are involved $(8,11-14)$. Related research has been showing a strong relationship between microorganisms present in abscesses or in patient lesions $(1,2)$ and the ones from snake oral cavities $(10,11,13)$.

In the present work, oral microbiota composition of snakes from the municipality of São José do Rio Preto, state of São Paulo, Brazil, was determined.

\section{MATERIALS AND METHODS}

All the analyzed snakes were from the municipality of São José do Rio Preto, state of São Paulo, and were maintained in captivity at the Animal House of São Paulo State University, São José do Rio Preto campus.

Animals that represented each one of ten snake species were chosen for oral cavity analysis. The ten species were: Boa constrictor, Bothrops alternatus, Bothrops pauloensis, Crotalus durissus, Eunectes murinus, Mastigodryas bifossatus, Micrurus frontalis, Phalotris mertensi, Philodryas nattereri and Waglerophis merremii.

The collection of buccal samples (teeth and mucous membrane) was performed after the animal had been immobilized. Its oral cavity was exposed and a swab, previously moistened in TSB (tryptic soy broth), was introduced. The samples were placed onto plates with blood agar (Difco, USA) and incubated at $36^{\circ} \mathrm{C}$, for 24 hours, in the Microbiology Laboratory of São José do Rio Preto Medical School, FAMERP.

Gram staining was performed on all different types of colonies that had grown on the agar surface. Afterwards, each colony was isolated in brain heart infusion (BHI) agar 
(Difco, USA) for subsequent biochemical identification using oxidase, catalase, sugar fermentation and DNase test.

Only one collected sample from each snake was used for the microbiological study. Bacteria isolated from snakes, classified according to genus and species, were analyzed by means of qualitative parameters for each buccal sample.

\section{RESULTS}

The test was positive for all buccal samples from animals that represented the following families: Boidae, Colubridae, Elapidae and Viperidae. Gram-negative bacilli (GNB), gram-positive bacilli (GPB), gram-positive cocci (GPC) and gram-negative cocci bacilli (GNCB) were isolated from each oral cavity. Higher bacterial diversity was found in the oral cavities of $M$. frontalis and $P$. nattereri (Table 1 ).

Bacterial classification, according to genus and species, was possible for Actinomyces sp. (M. frontalis), Bulkolderia sp. (E. murinus), Moraxella sp. (M. frontalis), Proteus sp. (B. constrictor), Sarcina sp. (P. nattereri), Bacillus subtilis (common in B. alternatus and P.mertensi), Staphylococcus aureus (M. frontalis), coagulase-negative staphylococci (C. durissus, E. murinus, M. bifossatus), and Yersinia enterocolitica (B. pauloensis). 
Table 1. Microbiota isolated from oral cavities of studied snakes

\begin{tabular}{cccc}
\hline Snakes & Family & Dentition & Microbiota \\
\hline Boa constrictor Linnaeus, 1758 & Boidae & Aglyph & GNB, GPB \\
Eunectes murinus Linnaeus, 1758 & Boidae & Aglyph & GPC, GNCB \\
Mastigodryas bifossatus Raddi, 1820 & Colubridae & Aglyph & GPC \\
Phalotris mertensi Hoge, 1955 & Colubridae & Opistoglyph & GPB \\
Philodryas nattereri Steindachner, 1870 & Colubridae & Opistoglyph & GPB, GPC, \\
Waglerophis merremii Wagler, 1824 & Colubridae & Aglyph & GNCB \\
Micrurus frontalis Duméril, Bibron \& & Elapidae & Proteroglyph & GPB, GPC, \\
Duméril, 1854 & & & GNCB \\
Bothrops alternatus Duméril, Bibron \& & Viperidae & Solenoglyph & GPB \\
Duméril, 1854 & & & GNB \\
Bothrops pauloensis Amaral, 1923 & Viperidae & Solenoglyph & GPC \\
Crotalus durissus Linnaeus, 1758 & Viperidae & Solenoglyph & GP: \\
\hline
\end{tabular}

GNB: gram-negative bacilli; GPB: gram-positive bacilli; GPC: gram-positive cocci; GNCB: gramnegative cocci bacilli.

\section{DISCUSSION}

Goldstein et al. (15), analyzing the oral cavity of the North American rattlesnake, isolated the coagulase-negative staphylococci, Proteus sp. and Pseudomonas sp. In another study, on nonpoisonous snakes, they found the coagulase-negative staphylococci, Acinetobacter sp., Hafnia alvei, Arizona hinshawii, Salmonella sp., Shigella sp., Klebsiella oxytoca and Pseudomonas aeruginosa (16).

In the current study, concerning the Viperidae snakes, Bacillus subtilis was isolated from B. alternatus, Yersinia enterocolitica from B. pauloensis and a coagulasenegative staphylococcus from $C$. durissus.

Jorge et al. (3), studying the microbiota from fangs and venom of Bothrops jararaca in São Paulo State, most frequently isolated the group D streptococci, Enterobacter sp., followed by Providencia rettgeri, Providencia sp., Escherichia coli, Morganella morganii and Clostridium sp.; and less frequently Staphylococcus aureus and grampositive bacilli.

In several Brazilian states, lesions caused by Bothrops envenomation - that were infected with gram-negative bacteria, gram-positive diplococcus, gram-positive cocci, 
Clostridium sp., Proteus sp., Enterobacter sp. and Klebsiella sp. - have been reported. Analysis of these lesions demonstrated the presence of aerobic and anaerobic bacteria $(3,7,8)$. Similarly, some of those bacteria found in lesions provoked by Bothrops were also isolated from the mouths of snakes studied in the present work, including Proteus sp. (from Boa constrictor), gram-positive bacilli and gram-negative bacilli from (Philodryas nattereri), coagulase-negative staphylococcus (from Crotalus durissus, Eunectes murinus and Mastigodryas bifossatus) and Staphylococcus aureus (from Micrurus frontalis).

Snakes can also host bacteria in their oral cavity. Aeromonas sp., Enterobater sp., Proteus sp., Pseudomonas sp., Staphylococcus sp. and Salmonella sp. have already been isolated from wounds and abscesses of snakes; the same microorganisms were found in human abscesses (17-21).

Draper et al. (7), studying the microbiota from oral cavities of healthy and sick snakes, found gram-positive bacteria in healthy animals, whereas the sick ones presented, most frequently, Pseudomanas, Providencia and gram-negative bacilli. In the current study, gram-positive bacilli were common to all oral cavities of the following snake families: Boidae, Colubridae, Elapidae and Viperidae.

These results reinforce what has been described in the literature $(3,12-14,16,22$, 23), regarding different countries, according to the diversity of the oral microbiota of the snakes, which can be considered nonspecific and associated with the environment, with animal feeding habits and seasonality $(11,20)$.

\section{ACKNOWLEDGEMENTS}

We are thankful to Arif Cais from the Department of Zoology and Botany, UNESP, São José do Rio Preto, SP, Brazil; to Carlos Eduardo Souza from UNESP Animal House, São José do Rio Preto, SP, Brazil; and to Jairo Ismael Cardoso From the Laboratory of Biology, FAFIBE Integrated Faculties, Bebedouro, SP, Brazil. 


\section{REFERENCES}

1. Andrade JG, Pinto RNL, Andrade ALSS, Martelli CMT, Zicher F. Estudo bacteriológico de abscessos causados por picada de serpentes do gênero Bothrops. Rev Inst Med Trop São Paulo. 1989;31(6):363-7.

2. Jorge MT, Mendonça JS, Ribeiro LA, Da Silva ML, Kusano EJU. Flora bacteriana em abscessos causados por picadas de serpentes do gênero Bothrops. In: 27 Congresso da Sociedade Brasileira de Medicina Tropical; 1991, Uberaba, MG. Livro de Programas e Resumos; 1991.

3. Jorge MT, Mendonça JS, Ribeiro LA, Da Silva MLR, Kusano EJU, Cordeiro CLS. Flora bacteriana da cavidade oral, presas e veneno de Bothrops jararaca: possível fonte de infecção no local da picada. Rev Inst Med Trop São Paulo. 1990;32:6-10.

4. Jorge MT, Ribeiro LA. Infections in the bite site after envenoming by snakes of the Bothrops genus. J Venom Anim Toxins 1997;3(2):264-72.

5. Oliveira RB, Ribeiro LA, Jorge MT. Fatores associados à incoagulabilidade sangüínea no envenenamento por serpentes do gênero Bothrops. Rev Soc Bras Med Trop. 2003;36(6):657-63.

6. Barraviera B, Pereira PCM. Acidentes por serpentes dos gêneros Bothrops, Lachesis e Micrurus: curso sobre acidentes por animais peçonhentos; $4^{\mathrm{a}}$ aula. Arq Bras Med. 1991;65(4):345-55.

7. Jorge MT, Ribeiro LA, Da Silva ML, Kusano EJ, Mendonça JS. Microbiological studies of abscesses complicating Bothrops snakebite in humans: a prospective study. Toxicon. 1994;32(6):743-8.

8. Quiroga M, Avila-Agüero ML, Faingezicht I. Abscess secondary to facial snakebite. J Venom Anim Toxins. 2000;6(2):261-70.

9. Saborió P, Gonzales M, Cambronero M. Snake bite accidents in children in Costa Rica: epidemiology and determination of risk factors in the development of abscess and necrosis. Toxicon. 1998;36(2):359-66.

10. Barraviera B. Acidentes por serpentes do gênero Crotalus. Arq Bras Med. 1989;64:14-20.

11. Blaylock RS. Normal oral bacterial flora from some southern African snakes. Onderstepoort J Vet Res. 2001;68(3):175-82.

12. Bolaños $R$, Brunker $T$. Bacteriología del veneno y de las glándulas veneníferas de Bothrops asper y Crotalus durissus de Costa Rica. Rev Cost Cienc Med. 1983;4:S27-S30. 
13. Talan DA, Citron DM, Overturf GD, Singer B, Froman P, Goldstein EJ. Antibacterial activity of crotalid venoms against oral snake flora and other clinical bacteria. J Infect Dis. 1991;164(1):195-8.

14. Theakston RD, Phillips RE, Looareesuwan S, Echeverria P, Makin T, Warrell DA. Bacteriological studies of the venom and mouth cavities of wild Malayan pit vipers (Calloselasma rhodostoma) in southern Thailand. Trans R Soc Trop Med Hyg. 1990;84(6):875-9.

15. Goldstein EJ, Citron DM, Gonzales H, RusselL FE, Finegold SM. Bacteriology of rattlesnake venom and implications for therapy. J Infect Dis. 1979;140(5):818-21.

16. Goldstein EJ, Agyare EO, Vagvolgyi AE, Halpern M. Aerobic bacterial oral flora of garter snakes: development of normal flora and pathogenic potential for snakes and humans. J Clin Microbiol. 1981;13(5):954-6.

17. Coutinho SDA, Carvalho VM, Ramos MCC, Costa EO, Diniz LS, Guimarães MABV, Borges MR. Bacterial septicemia in water snakes (Helicops modestus) in Brazil. Arq Bras Med Vet Zootec. 2001;53(4):1-2.

18. Hejnar P, Bardon J, Sauer P, Kolar M. Stenotrophomonas maltophilia as a part of normal oral bacterial flora in captive snakes and its susceptibility to antibiotics. Vet Microbiol. 2007;121(3-4):357-62.

19. Silva RJ. As serpentes. Jaboticabal: Funep; 2000.

20. Soveri T. Observations of bacterial diseases of captive snakes in Finland. Nord Vet Med. 1984;36(1-2):38-42.

21. Soveri T, Seuna ER. Aerobic oral bacteria in healthy captive snakes. Acta Vet Scand. 1986;27(2):172-81.

22. Draper CS, Walker RD, Lawler HE. Patterns of oral bacterial infection in captive snakes. J Am Vet Med Assoc. 1981;179(11):1223-6.

23. Kerrigan KR. Bacteriology of snakebite abscess. Trop Doct. 1992;22(4):158-60. 